\title{
ILNESS PERCEPTION DAN SENSE OF COHERENCE (SOC) PADA PASIEN DIABETES MELITUS TIPE 2
}

\author{
Christiani Natasya Miru, Krismi Diah Ambarwati \\ Fakultas Psikologi, Universitas Kristen Satya Wacana Salatiga \\ christianimiru@gmail.com
}

\begin{abstract}
ABSTRAK. Penelitian ini bertujuan untuk mengetahui ada atau tidaknya hubungan antara illness perception dengan Sense of Coherence (SOC) pada pasien Diabetes Melitus tipe 2. SOC adalah orientasi global sejauh mana seseorang memiliki perasaan percaya diri yang persuasif, abadi, dan dinamis bahwa stimulus yang berasal dari lingkungan internal dan eksternal dalam kehidupan adalah sesuatu yang terstruktur, dapat diprediksi, dan dapat dijelaskan; sumber daya tersedia bagi seseorang untuk memenuhi tuntutan yang ditimbulkan dari stimulus; tuntutan merupakan tantangan dan keterikatan dalam kehidupan, dengan salah satu faktor yang memengaruhi SOC adalah illness perception. Partisipan dalam penelitian adalah 58 pasien DM tipe 2 di Puskesmas Kedungmundu Kota Semarang. Data diambil dengan menggunakan metode kuantitatif dengan model purposive sampling. Hasil penelitian menunjukkan koefisien korelasi $\left(\mathrm{r}_{\mathrm{xy}}\right)=0,536$ dengan nilai signifikansi $0,000(\mathrm{p}<0,05)$ yang berarti terdapat hubungan positif yang signifikan antara illness perception dan Sense of Coherence pada pasien Diabetes Melitus tipe 2 di Puskesmas Kedungmundu Kota Semarang.
\end{abstract}

Kata kunci: Illness Perception; Sense of Coherence

ABSTRACT. This study aims to determine whether or not there is a relationship between illness perception and Sense of Coherence (SOC) in patients with type 2 diabetes mellitus. Sense of Coherence (SOC) is a global orientation that states the extent to which a person has feelings of confidence that are persuasive, lasting, and dynamic that stimulus that comes from a person's internal and external environment in his life is something that is structured, predictable, and can be explained; resources available to someone to meet demands arising from the stimulus; claims are challenges and attachment to life, with one of the factors which affect SOC, namely illness perception. Participants in the study were 58 type 2 DM patients at the Kedungmundu Health Center, Semarang City. Data was collected using quantitative methods with a purposive sampling model. Based on the research results obtained correlation coefficient $\left(r_{x y}\right)=0.536$ with a significance value of $0.000(p<0.05)$ which means there is a significant positive relationship between illness perception and Sense of Coherence in patients with type 2 Diabetes Mellitus in Kedungmundu Health Center Semarang City.

Keywords: Illness Perception; Sense of Coherence

\section{PENDAHULUAN}

World Health Organisation (2015) mendefinisikan Diabetes Melitus (DM) sebagai penyakit kronis yang disebabkan oleh defisiensi bawaan dan/atau dari produksi insulin oleh pankreas atau karena ketidakefektifan insulin yang diproduksi. WHO membagi tipe diabetes menjadi dua yaitu DM tipe 1 dan DM tipe 2. DM tipe 1 adalah tipe diabetes yang ditandai dengan kekurangan insulin dalam tubuh sejak masa kanak-kanak sedangkan DM tipe 2 adalah tipe diabetes yang terjadi karena penggunaan 
insulin yang tidak efektif dalam tubuh. Dalam Global Report on Diabetes, DM tipe 2 menyumbang sebagian besar orang dengan diabetes di seluruh dunia.

Berdasarkan data dari International Diabetes Federation (IDF) pada tahun 2017 diketahui jumlah pasien DM di Indonesia pada kelompok umur antara 20-79 tahun pada tahun 2017 diperkirakan sebanyak 10,3 juta yang menempatkan Indonesia pada urutan ke 7 di dunia, sedangkan pada tahun 2045 diperkirakan jumlahnya meningkat menjadi 16,7 juta dan menempatkan Indonesia pada urutan ke 7. Dalam Profil Kesehatan Kota Semarang (2017) menyebutkan bahwa penyakit DM tipe 2 berada pada urutan kelima dari sepuluh penyakit terbesar di Puskesmas Semarang dengan jumlah kasus 25.608 kasus. Profil Kesehatan Kota Semarang (2015) menyatakan bahwa Puskesmas Kedungmundu merupakan salah satu Puskesmas dengan kasus DM terbesar di Kota Semarang dengan proporsi kasus sebesar 30,3\% pada tahun 2015 .

Pengobatan paling dasar bagi DM tipe 2 adalah gaya hidup sehat yang meliputi penerapan pola makan sehat, peningkatan aktivitas fisik, rencana berhenti merokok dan pemeliharaan berat badan yang sehat kemudian didukung dengan penggunaan obat oral (IDF, 2017). Oleh karena itu pasien DM tipe 2 perlu melakukan manajemen penyakit dengan melakukan modifikasi diet, aktivitas fisik, terapi pengobatan dan pemeriksaan gula darah secara teratur, namun karena manajemen penyakit ini memerlukan waktu yang sangat lama membuat sebagian besar pasien menjadi tidak patuh (Rahmawati, Setiawati, \& Solehati, 2014). Funnel dan Anderson (2004) menyatakan bahwa para tenaga kesehatan sudah mendorong dan membujuk pasien diabetes untuk melakukan tugas perawatan diri, namun pasien tidak mau mengikuti saran sehingga tidak dapat mencapai hasil yang diinginkan padahal dapat dikatakan keberhasilan pasien untuk mengelola penyakit diabetes dinilai dari kemampuan pasien mengikuti terapi.

$$
\text { Pernyataan tersebut mendukung }
$$

fenomena yang terjadi saat ini adalah semakin banyak orang mengalami penyakit DM tipe 2 namun hanya sedikit orang yang dapat sembuh atau dapat mengelola dengan baik sakit yang dideritanya. Perawatan dan manajemen diri pada pasien dengan penyakit kronis dipengaruhi oleh Sense of Coherence (SOC) dalam diri individu (Gallagher, Donoghue, Chenoweth, \& Stein-Parbury, 2008).

Konsep SOC pertama kali diperkenalkan oleh Antonovsky (1987) sebagai bagian dari teori salutogenik, yang meneliti mengapa beberapa orang ketika menghadapi sebuah stressor dan peristiwa kehidupan traumatis tetap sehat sementara yang lain tidak. Antonovky memperkenalkan teori salutogenik, di mana adaptasi koping adalah gerakan rahasia menuju akhir yang sehat dari suatu penyakit, sehingga akhirnya ia mengenalkan teori SOC yang fokus pada teori salutogenik seperti kekuatan dan faktor penentu kesehatan dibandingkan pada teori patogenik yang berfokus pada faktor risiko dari suatu penyakit (Antonovksy, 1993). Sense of Coherence (SOC) didefinisikan sebagai sebuah orientasi global yang menyatakan sejauh mana seseorang memiliki perasaan percaya diri yang persuasif, abadi, dan dinamis bahwa (1) stimulus yang berasal dari lingkungan internal dan eksternal seseorang dalam kehidupannya adalah sesuatu yang terstruktur, dapat diprediksi, dan dapat dijelaskan; (2) sumber daya tersedia bagi seseorang untuk memenuhi tuntutan yang ditimbulkan dari stimulus; (3) tuntutan merupakan tantangan, sebuah investasi yang layak dan keterikatan dalam kehidupan (Antonovsky, 1987).

SOC terdiri dari tiga dimensi yaitu comprehensibility, manageability dan meaningfulness. Comprehensibility menyangkut kecenderungan untuk memiliki keyakinan bahwa apa yang terjadi dalam hidup mereka adalah rasional, dapat diprediksi, terstruktur, dan dapat dipahami. Manageability adalah persepsi umum tentang kecukupan sumber daya untuk individu memadai dan dapat membantu individu untuk 
menyelesaikan kesulitan yang timbul. Meaning mengacu sejauh mana seseorang percaya bahwa tuntutan yang terjadi karena kesulitan-kesulitan adalah suatu tantangan dan layak untuk diperjuangkan dan bermanfaat dan memotivasi individu tersebut (Surtees, Wainwright, Luben, Khaw \& Day, 2003).

Dalam penelitian yang dilakukan oleh Gallagher et al (2008) menyatakan bahwa SOC merupakan salah satu karakteristik kepribadian yang memengaruhi motivasi seseorang secara keseluruhan untuk tetap sehat dan perilaku koping bagi penyakit kronis. DM tipe 2 merupakan salah satu penyakit kronis sehingga dapat dilihat sebagai sebuah stressor bagi pasien. Seorang individu dengan dengan SOC yang kuat lebih cenderung menilai situasi stressor sebagai sesuatu yang dapat dikendalikan dan dapat memilih strategi manajemen yang tepat (Antonovsky, 1993). SOC mencerminkan kemampuan individu untuk beradaptasi dengan stres (Hakanen, Feldt, \& Leskinen, 2007; Volanen, Suominen, Lahelma, Koskenvuo, Silventoinen, 2007). Selain itu, pada penelitian-penelitian sebelumnya, dijelaskan bahwa SOC pada seseorang yang diabetes terkait dengan strategi koping yang digunakan untuk merawat penyakit tersebut (Li \& Shiu, 2008; Lundman \& Norberg, 1993). SOC juga berperan dalam kontrol gula darah yang dilakukan oleh pasien diabetes sebagai bagian dari manajemen penyakit (Cohen \& Kanter, 2004). Selain itu, telah disarankan bahwa dengan meningkatkan SOC dalam kehidupan sehari-hari berguna untuk manajemen diri pasien dengan komplikasi diabetes (Leksell, Wikblad, \& Sandberg, 2005).

Penelitian-penelitian sebelumnya menunjukkan bahwa SOC memberikan kontribusi bagi pasien dengan DM tipe 2 untuk mengendalikan dan melakukan manajemen penyakitnya dengan tepat. Penelitian yang dilakukan Lo Sterzo dan Orgeta (2015) pada pengasuh (caregiver) pasien demensia menunjukkan bahwa persepsi terhadap penyakit demensia memengaruhi SOC pengasuh. Persepsi penyakit dapat memengaruhi adaptasi psikologis dan mengatasi stres yang berhubungan dengan penyakit (Leventhal et al., 2003). Hal ini menunjukkan bahwa persepsi penyakit tidak hanya membantu seseorang untuk memahami bagaimana ia memandang penyakitnya, tetapi juga bagaimana atribusi penyakit dapat memengaruhi penyesuaian dan penanganan psikologis dalam kehidupannya (Lo Sterzo \& Orgeta, 2015). Persepsi terhadap penyakit atau illness perception didefinisikan sebagai keyakinan-keyakinan dan harapan-harapan mengenai penyakit atau gejala somatis yang dialami (Leventhal, 1970; Leventhal, Meyer, \& Nerenz, 1980; dalam Sutton, Baum, \& Johnston, 2004).

Illness perception terdiri dari 9 dimensi (Leventhal, Nerenz, \& Steele, 1984; dalam Sutton et al, 2004), yaitu: (1) Consequences keyakinan individu tentang beratnya penyakit dan kemungkinan besar berdampak pada pemfungsian fisik, sosial dan psikologis (Leventhal et al, 1984; dalam Weinman, Petrie, Moss-Morris, \& Horne, 1996); (2) Timeline - persepsi mengenai lamanya permasalahan kesehatan berlangsung yang dapat dikategorikan menjadi akut atau jangka pendek, kronis dan siklus atau episodik (Leventhal et al, 1984; dalam Weinman et al, 1996); (3) Personal Control - keyakinan (belief) tentang bagaimana diri sendiri mampu mengontrol gejala-gejala dari penyakit yang diderita (Moss-Morris, Weinman, Petrie, Horne, Cameron, \& Buick, 2002) (4) Treatment Control - keyakinan terhadap pengobatan atau nasihat yang direkomendasikan (seperti harapan-harapan terhadap hasil) (Moss-Morris et al, 2002); (5) Identity - ide pasien tentang nama, kondisi mereka pada dasarnya (gejala-gejala yang berhubungan), dan hubungan diantara keduanya (Leventhal et al,1984; dalam Weinman et al, 1996); (6) Concern keyakinan pasien bahwa dirinya sangat memberikan perhatian terhadap penyakit yang diderita; (7) Illness Coherence - Tipe metakognisi yang menggambarkan arah di 
mana pasien mengevaluasi kelogisan atau manfaat dari illness perception yang dimiliki (Moss-Morris et al, 2002); (8) Emotions keyakinan tentang reaksi-reaksi emosi seseorang terhadap penyakit yang dideritanya (Moss-Morris et al, 2002); (9) Causal Representation - faktor yang diyakini menyebarkan berkembangnya penyakit oleh seseorang (Leventhal et al, 2008; dalam Taylor, 2009).

Peneliti melihat bahwa pasien DM tipe 2 dengan illness perception yang baik akan mengembangkan SOC yang baik sehingga dapat melakukan perawatan diri dan manajemen penyakit secara optimal. Hal ini didukung oleh penelitian yang dilakukan Lo Sterzo dan Orgeta (2015) yang menjelaskan bahwa aspek penting dari SOC, seperti kemampuan untuk membingkai ulang stressor sebagai tantangan, menemukan makna dan perasaan percaya diri untuk mengelola situasi terkait erat dengan aspek kognitif dan aspek afektif dari persepsi demensia sebagai penyakit. Pengasuh yang memiliki persepsi negatif demensia, cenderung menganggap hidup kurang bermakna, memiliki sumber daya yang lebih sedikit untuk mengatasi peristiwa sulit dan kurang mampu mengelola situasi. Di sisi lain, pengasuh dengan persepsi penyakit demensia yang baik memiliki SOC lebih tinggi dan dapat berkontribusi pada pemberian perawatan yang lebih baik pada pasien demensia.

Di sisi lain, penelitian yang dilakukan oleh Graham, Ballard dan Sham (1997) menunjukkan hasil yang berbeda di mana pengasuh yang memiliki pengetahuan yang lebih besar mengenai penyakit mengalami tingkat kecemasan yang lebih tinggi sehingga mengakibatkan tekanan psikologis yang lebih besar. Pengetahuan akan penyakit termasuk dalam salah satu dimensi illness perception yaitu identity. Tingkat kecemasan yang lebih tinggi pada pengasuh yang memiliki pengetahuan lebih besar dikarenakan informasi yang mereka peroleh membuat mereka menjadi sadar akan tingkat keparahan gangguan atau dikarenakan mereka gelisah untuk mencari pengetahuan tentang penyakit itu sehingga membuat pengasuh merasa tidak memiliki kontrol yang lebih besar atas situasi yang terjadi (Graham et al, 1997; Proctor, Martin, \& Hewison, 2002). Dari uraian tersebut, dapat disimpulkan bahwa pengasuh yang memiliki illness perception yang baik khususnya pada dimensi identity menjadi kurang memiliki kontrol atas situasi yang terjadi dalam hidupnya yang merupakan bagian dimensi manageability pada SOC.

Penelitian mengenai SOC telah banyak dilakukan pada pasien dengan penyakit kronis. Abdelgadir, Shebeika, Eltom, Berne, dan Wikblad (2009) menemukan bahwa SOC terkait dengan Quality of Life (QOL) pada pasien diabetes. Sanden-Eriksson (2000) mempelajari 88 orang dengan DM tipe 2 dan menemukan bahwa mereka yang memiliki kesehatan lebih baik menunjukkan SOC yang lebih tinggi. SOC yang rendah dikaitkan dengan perilaku berisiko kesehatan, seperti konsumsi alkohol berbahaya (Neuner et al, 2006), aktivitas fisik yang lebih rendah (Kuuppelomaki \& Utriainen, 2003) dan pilihan makanan yang tidak sehat (Lindmark, Stegmayr, \& Nilsson, 2005). SOC yang lebih lemah dikaitkan dengan kesehatan yang lebih buruk dan memerlukan lebih banyak dukungan untuk mengelola penyakit secara efektif dalam studi oleh Langius dan Bjo“rvell (1996). Selain itu, SOC yang kuat secara signifikan terkait dengan kurangnya pengalaman kesepian, suasana hati tertekan, stres dan kecemasan, dan kurang nyeri dada 1 tahun setelah operasi cangkok bypass arteri koroner pada 110 pasien (Karlsson, Berglin, Pettersson, \& Larsson, 2000). Sebagai prediktor kesehatan, SOC telah membuktikan hubungannya dengan kualitas hidup (Delgado, 2007) dan kesejahteraan psikologis (Pallant \& Lae, 2002).

Odajima dan Sumi (2017) juga menyatakan bahwa penelitian mengenai kegunaan salutogenesis untuk beban penderita diabetes dan kontrol gula darah sebagai bagian dari manajemen diri pada penderita diabetes belum mencukupi, oleh karena itu dengan meneliti kembali faktor-faktor yang berkaitan dengan SOC dalam konsep 
salutogenesis akan bermanfaat. Hal inilah yang mendasari peneliti untuk meneliti salah satu faktor yang berkontribusi pada SOC yaitu illness perception. Selain itu, penelitian mengenai illness perception dan sense of coherence sebelumnya dilakukan pada pengasuh pasien demensia (Lo Sterzo \& Orgeta, 2005) sedangkan peneliti melihat bahwa illness perception dan sense of coherence penting untuk dimiliki pasien yang mengalami penyakit sehingga dapat melakukan manajemen diri pada penyakit yang diderita.

Tujuan dari penelitian ini untuk mengetahui hubungan antara Illness Perception dengan Sense of Coherence (SOC) pada pasien Diabetes melitus tipe 2 di Puskesmas Kedungmundu Kota Semarang. Hal ini nantinya akan bermanfaat bagi pasien DM tipe 2 sehingga diharapkan dapat meningkatkan illness perception yang berperan pada SOC pasien sehingga mampu melakukan manajemen penyakit DM tipe 2 dengan optimal, manfaat lainnya bagi caregiver DM tipe 2 untuk bisa memberikan dukungan mengembangkan SOC dalam diri pasien sehingga pasien dapat melakukan manajemen penyakitnya dengan baik. Selain itu, hasil dari penelitian ini dapat digunakan sebagai referensi tambahan untuk penelitian selanjutnya mengenai illness Perception dan SOC.

Hipotesis dalalm penelitian ini adalah hubungan yang positif signifikan antara Illness Perception dengan Sense of Coherence pada pasien Diabetes Melitus tipe 2 di Puskesmas Kedungmundu Kota Semarang.

\section{METODE}

Penelitian ini menggunakan metode penelitian kuantitatif korelasional. Variabel penelitian yang digunakan dalam penelitian ini adalah Illness Perception sebagai variabel bebas (X, independent) dan Sense of Coherence sebagai variabel terikat (Y, dependent).

Penelitian ini dilakukan di Puskesmas Kedungmundu, Kec. Tembalang, Kota Semarang, Jawa Tengah. Populasi yang diambil adalah jumlah pasien DM tipe 2 per Agustus 2019 yaitu 387 orang. Dalam menentukan besaran sampel, peneliti menggunakan $15 \%$ dari jumlah populasi yaitu sebanyak 58 pasien DM tipe 2 yang berdasar pada teori dari Arikunto (2002), bahwa jika subjek lebih besar dari 100 dapat diambil antara $10 \%-15 \%$ atau $20-25 \%$ dari jumlah populasi. Teknik sampling yang digunakan adalah purposive sampling yaitu pengambilan sampel yang dilakukan dengan berdasarkan kriteria-kriteria tertentu (Sugiyono, 2006).

Adapun kriterianya antara lain:

1. Merupakan pasien DM tipe 2 (terdiagnosis DM tipe 2 menurut kriteria diagnosis WHO).

2. Usia minimal 30 tahun, karena menurut Antonovsky (1987) SOC sepenuhnya berkembang dan stabil di sekitar usia 30 tahun.

3. Telah menderita DM tipe 2 minimal 3 bulan, karena DM tipe 2 adalah penyakit kronis. Istilah kronis diterapkan ketika penyakit diderita dalam jangka waktu tiga bulan atau lebih (Bernell \& Howard, 2016).

4. Sedang menjalani rawat jalan di Puskesmas Kedungmundu.

5. Pasien tidak sedang mengalami gangguan kejiwaan/psikologis.

6. Dapat membaca dan memahami instrument BIPQ versi Indonesia dan bersedia berpartisipasi dalam penelitian.

Dalam mengumpulkan data, peneliti datang berkunjung ke kegiatan Prolanis yang diadakan di Puskesmas pada tanggal 10 dan 12 Oktober. Pada hari pertama peneliti mengumpulkan data sebanyak 28 skala, sedangkan pada hari kedua peneliti dapat mengumpulkan data sebanyak 30 skala. Dalam pengisian skala, peneliti ikut mendampingi partisipan. Dari 58 partisipan, diperoleh data demografis sebagai berikut: 
Grafik 1. Kategori jenis kelamin partisipan Jenis Kelamin

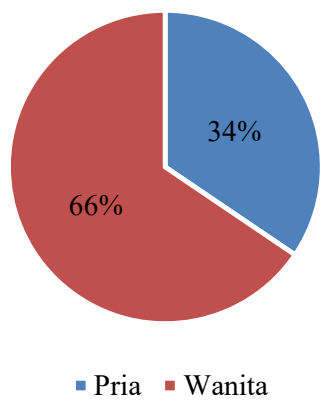

Pada grafik 1, dijelaskan bahwa jumlah partisipan dalam penelitian ini didominasi oleh partisipan pria sebanyak 20 orang dengan persentase sebesar 34\% sedangkan partisipan wanita sebanyak 38 orang dengan persentase $66 \%$.

Grafik 2. Kategori usia partisipan

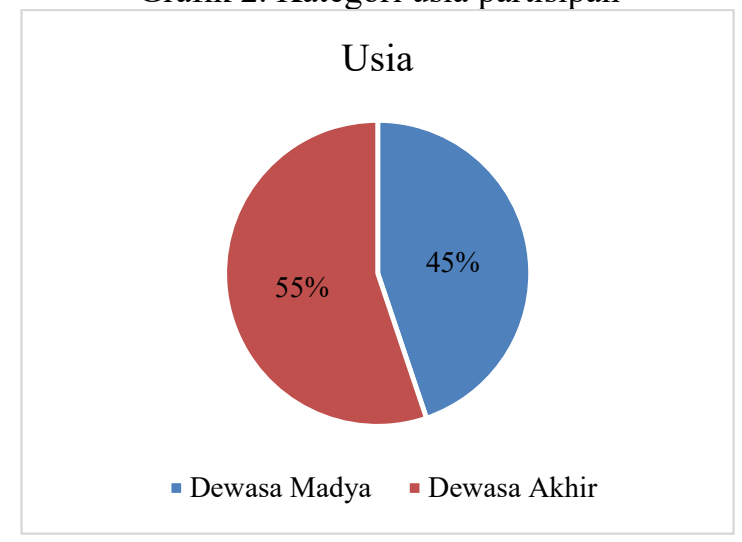

Pada grafik 2, dijelaskan bahwa jumlah partisipan dalam penelitian ini didominasi oleh partisipan dengan kategori usia pada masa dewasa akhir ( $>60$ tahun) sebanyak 32 orang dengan persentase $55 \%$ sedangkan partisipan dengan kategori usia pada masa dewasa madya (40-60 tahun) sebanyak 26 orang dengan persentase sebesar $45 \%$.
Grafik 3. Lama mengidap DM tipe 2

Lama mengidap DM tipe 2

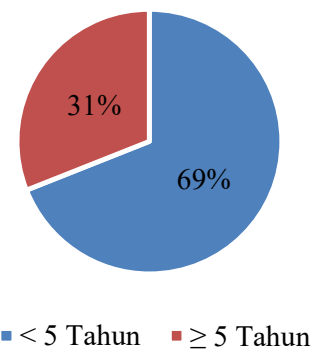

Pada grafik 3, dijelaskan bahwa jumlah partisipan dalam penelitian ini didominasi oleh partisipan dengan lama mengidap DM tipe 2 dalam kurun waktu $<5$ tahun sebanyak 40 orang dengan persentase $69 \%$ sedangkan partisipan dengan lama mengidap DM tipe 2 dalam kurun waktu $\geq 5$ tahun sebanyak 18 orang dengan persentase sebesar $31 \%$.

\section{Metode Pengumpulan Data}

1. Brief Illness Perception Questionnaire (BIPQ)

Alat ukur Brief Illness Perception Questionnaire (BIPQ) dikembangkan oleh Broadbent, Petrie, Main, dan Weinman pada tahun 2006 dengan sembilan dimensi illness perception berdasarkan Leventhal's Self Regulation Model (Broadbent et al, 2006). BIPQ memiliki sembilan item yang mewakili tiap dimensi. Lima item menilai representasi kognitif dari penyakit yaitu: consequences (Item 1), timeline (Item 2), personal control (Item 3), treatment control (Item 4), dan identity (Item 5). Dua item menilai representasi emosional dari penyakit yaitu: concern (Item 6) dan emotions (Item 8). Satu item menilai illness coherence (Item 7). Satu item menilai representasi kausal dari penyakit dan merupakan item respon terbuka yang meminta pasien membuat daftar tiga faktor penyebab paling penting dalam penyakit mereka yaitu causal representation (Item 9). Semua item kecuali pertanyaan kausal dinilai menggunakan skala respons 0 hingga 10 . BIPQ-R versi Indonesia telah diuji coba pada 
Pasien Hipertensi di RSUD Sultan Syarif Mohamad Alkadrie Pontianak dan menghasilkan nilai reliabilitas sebesar 0,807 sehingga dapat dikatakan bahwa skala tersebut sudah reliabel (Robiyanto, Prayuda, \& Nansy, 2016).

Dalam melalukan analisis daya diskriminasi item-item digunakan ketentuan Azwar (2012), yaitu item dikatakan berdiskriminasi baik apabila korelasi tiap faktor bernilai positif dan sebesar 0,30. Hasil yang diperoleh dari satu kali perhitungan data pada skala illness perception yang terdiri dari 8 item, tidak terdapat item yang gugur dan item berdiskiriminasi baik dengan nilai reliabilitas sebesar 0,801 sehingga dapat disimpulkan skala tersebut reliabel dan dapat digunakan sebagai alat ukur penelitian.

\section{Sense of Coherence Scale (SOC-29)}

Alat ukur Sense of Coherence Scale (SOC-29) milik Antonovsky kemudian diadaptasi oleh peneliti dari Paika, Ntountoulaki, Papaioannou, dan Hyphanti pada tahun 2017. Sense of Coherence Scale (SOC-29) memiliki 29 item yang terdiri dari 3 aspek. Pada aspek comprehensibility terdapat 11 item, pada aspek manageability terdapat 10 item sedangkan pada aspek meaningfulness terdiri dari 8 item. Alat ukur

ini telah diuji coba oleh Paika, et al (2017) dan menghasilkan nilai reliabilitas sebesar 0,90 sehingga dapat dikatakan bahwa skala tersebut sudah reliabel. Dalam melalukan analisis daya diskriminasi item-item digunakan ketentuan Azwar (2012), yaitu item dikatakan berdiskriminasi baik apabila korelasi tiap faktor bernilai positif dan sebesar 0,30 . Hasil yang diperoleh dari dua kali perhitungan data pada skala sense of coherence yang terdiri dari 29 item masih tersisa 22 item yang berdiskiriminasi baik dengan nilai reliabilitas 0,851 sehingga dapat disimpulkan skala tersebut reliabel dan dapat digunakan sebagai alat ukur penelitian.
HASIL

\section{Analisis Deskriptif \\ Illness Perception}

Tabel 1. Kategorisasi Skor Variabel Illness Perception

\begin{tabular}{ccccc}
\hline Kategori & Interval & Frek & Persen & Mean \\
\hline Tinggi & $53 \leq \mathrm{X}<80$ & 19 & $32,8 \%$ & \\
\hline Sedang & $26 \leq \mathrm{X}<53$ & 34 & $58,6 \%$ & 45,69 \\
\hline Rendah & $0 \leq \mathrm{X}<26$ & 5 & $8,6 \%$ & \\
\hline Jumlah & \multicolumn{5}{c}{58} & $100 \%$ \\
\hline \multicolumn{5}{c}{$\mathrm{SD}=14,41 ; \mathrm{Max}=77 ; \mathrm{Min}=16$} \\
\hline
\end{tabular}

Pada tabel 1 kategori skor variabel illness perception dari sejumlah 70 partisipan menunjukkan tingkat penyebaran kategori dari rendah, sedang dan tinggi. Dapat dilihat bahwa pada illness perception pasien DM tipe 2 yang berada pada kategori tinggi sebanyak 19 orang $(32,8 \%)$, yang berada pada kategori sedang sebanyak 34 orang $(58,6 \%)$, dan yang berada pada kategori rendah sebanyak 5 orang $(8,6 \%)$. Dari tabel juga dapat dilihat bahwa mean/rata-rata sebesar 45,09 yang berada pada kategori sedang.

\section{Sense of Coherence}

Tabel 2. Kategorisasi Skor Variabel Sense of Coherence

\begin{tabular}{|c|c|c|c|c|}
\hline Kategori & Interval & Frek & Persen & Mean \\
\hline & $110 \leq X<$ & & & \\
\hline Tinggi & 154 & 23 & $39,7 \%$ & \\
\hline & $66 \leq X<$ & & & \\
\hline Sedang & 110 & 33 & $56,9 \%$ & 103,47 \\
\hline & $22 \leq X<$ & & & \\
\hline Rendah & 66 & 2 & $3,4 \%$ & \\
\hline Jumlah & & 58 & $100 \%$ & \\
\hline \multicolumn{5}{|c|}{$\mathrm{SD}=18,71 ; \mathrm{Max}=141 ; \mathrm{Min}=50$} \\
\hline
\end{tabular}

Pada tabel 2 kategori skor variabel sense of coherence dari sejumlah 70 partisipan menunjukkan tingkat penyebaran kategori dari rendah, sedang dan tinggi. Dapat dilihat bahwa pada sense of coherence pasien DM tipe 2 yang berada pada kategori tinggi sebanyak 23 orang $(39,7 \%)$, yang berada pada kategori sedang sebanyak 33 orang $(56,9 \%)$, dan yang berada pada kategori rendah sebanyak 2 orang (3,4\%). Dari tabel juga 
dapat dilihat bahwa mean/rata-rata sebesar 103,47 yang berada pada kategori sedang.

Selain itu, peneliti juga membagi kategori illness perception dan sense of coherence berdasarkan kategori jenis kelamin, usia dan lama mengidap penyakit DM tipe 2 .

Grafik 4. Kategorisasi Illness Perception berdasarkan data demografi

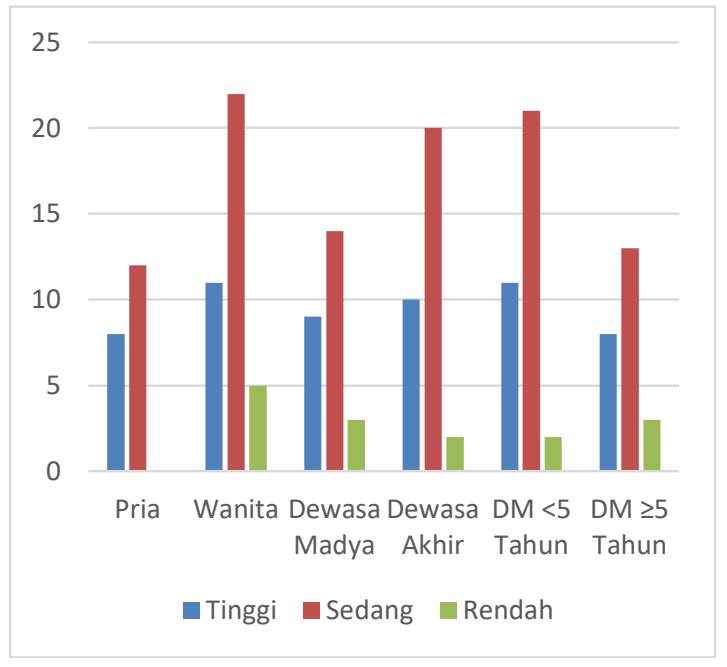

Berdasarkan grafik di atas, diketahui bahwa variabel illness perception partisipan pria kebanyakan berada pada kategori sedang sebanyak 12 orang, pada partisipan wanita kebanyakan berada pada kategori sedang sebanyak 22 orang, pada partisipan dewasa madya kebanyakan berada pada kategori sedang sebanyak 14 orang, pada partisipan dewasa akhir kebanyakan berada pada kategori sedang sebanyak 20 orang, pada partisipan yang mengidap DM tipe $2<5$ tahun kebanyakan berada pada kategori sedang sebanyak 21 orang, dan pada partisipan yang mengidap DM tipe $2 \geq 5$ tahun kebanyakan berada pada kategori sedang sebanyak 13 orang.
Grafik 5. Kategorisasi Sense of Coherence berdasarkan data demografi

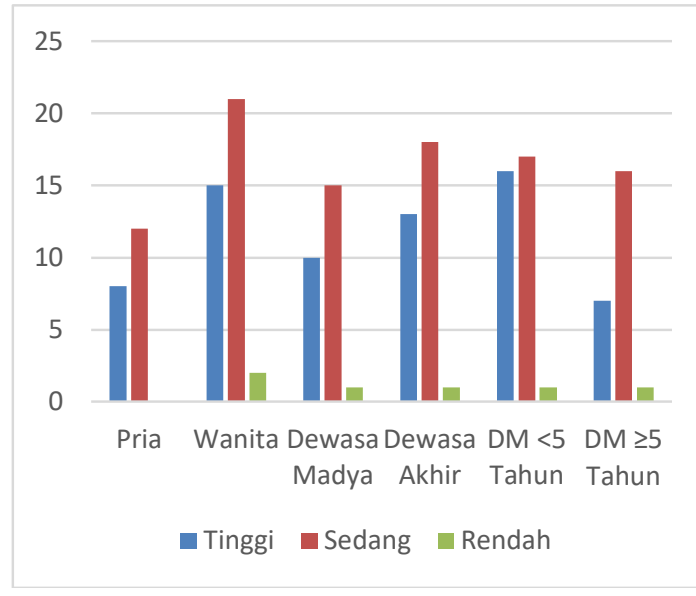

Berdasarkan grafik di atas, diketahui bahwa variabel sense of coherence partisipan pria kebanyakan berada pada kategori sedang sebanyak 12 orang, pada partisipan wanita kebanyakan berada pada kategori sedang sebanyak 21 orang, pada partisipan dewasa madya kebanyakan berada pada kategori sedang sebanyak 15 orang, pada partisipan dewasa akhir kebanyakan berada pada kategori sedang sebanyak 18 orang, pada partisipan yang mengidap DM tipe $2<5$ tahun kebanyakan berada pada kategori sedang sebanyak 17 orang, dan pada partisipan yang mengidap DM tipe $2 \geq 5$ tahun kebanyakan berada pada kategori sedang sebanyak 16 orang. 


\section{Uji Asumsi}

\section{Uji Normalitas}

Tabel 3. Normalitas Skala Illness Perception dan Sense of Coherence

\begin{tabular}{|c|c|c|c|}
\hline \multicolumn{4}{|c|}{ One-Sample Kolmogorov-Smirnov Test } \\
\hline & & $\begin{array}{l}\text { Illness } \\
\text { Perceptio } \\
\mathrm{n}\end{array}$ & $\begin{array}{c}\text { Sense } \\
\text { of } \\
\text { Cohere } \\
\text { nce }\end{array}$ \\
\hline \multicolumn{2}{|r|}{$\mathrm{N}$} & 58 & 58 \\
\hline \multirow[t]{2}{*}{$\begin{array}{l}\text { Normal } \\
\text { Parameters }{ }^{\mathrm{a}, \mathrm{b}}\end{array}$} & Mean & $9^{45,6}$ & 103,47 \\
\hline & $\begin{array}{r}\text { Std. } \\
\text { Deviation } \\
\end{array}$ & $15^{14,4}$ & 18,713 \\
\hline \multirow{3}{*}{$\begin{array}{l}\text { Most Extreme } \\
\text { Differences }\end{array}$} & Absolute &, 102 &, 093 \\
\hline & Positive &, 102 & 091 \\
\hline & Negative &, $083^{-}$ &,- 093 \\
\hline \multicolumn{2}{|c|}{ Kolmogorov-Smirnov Z } & ,775 & ,710 \\
\hline \multicolumn{2}{|c|}{ Asymp. Sig. (2-tailed) } & ,586 & ,694 \\
\hline
\end{tabular}

Uji normalitas menggunakan uji Kolmogrov-Smirnov yang menunjukkan variabel illness perception memiliki nilai $\mathrm{K}$ S-Z sebesar 0,775 dengan signifikansi sebesar $0,00 \quad(\mathrm{p}>0,05)$. Pada variabel sense of coherence memiliki nilai K-S-Z sebesar 0,710 dengan signifikansi sebesar 0,00 ( $\mathrm{p}>0,05)$. Dengan demikian dapat disimpulkan bahwa variabel illness perception dan sense of coherence berdistribusi normal.

\section{Uji Linearitas}

Tabel 4. Linearitas Skala Illness Perception dan Sense of Coherence

Correlations

\begin{tabular}{|c|c|c|c|}
\hline & & IP & SOC \\
\hline \multirow[t]{3}{*}{ IP } & Pearson Correlation & 1 &, $536 * *$ \\
\hline & Sig. (1-tailed) & &, 000 \\
\hline & $\mathrm{N}$ & 58 & 58 \\
\hline \multirow[t]{3}{*}{ SOC } & Pearson Correlation &, $536^{* *}$ & 1 \\
\hline & Sig. (1-tailed) &, 000 & \\
\hline & $\mathrm{N}$ & 58 & 58 \\
\hline
\end{tabular}

Dari hasil uji linearitas tabel 4 diperoleh nilai $\mathrm{F}$ beda dari deviation from linearity sebesar 0,930 dengan nilai signifikansi 0,580 $(p>0,05)$ yang menunjukkan terdapat hubungan linear antara variabel illness perception dan sense of coherence.

\section{UJI HIPOTESIS}

\section{Tabel 5. Korelasi Antara Illness Perception} Dengan Sense of Coherence

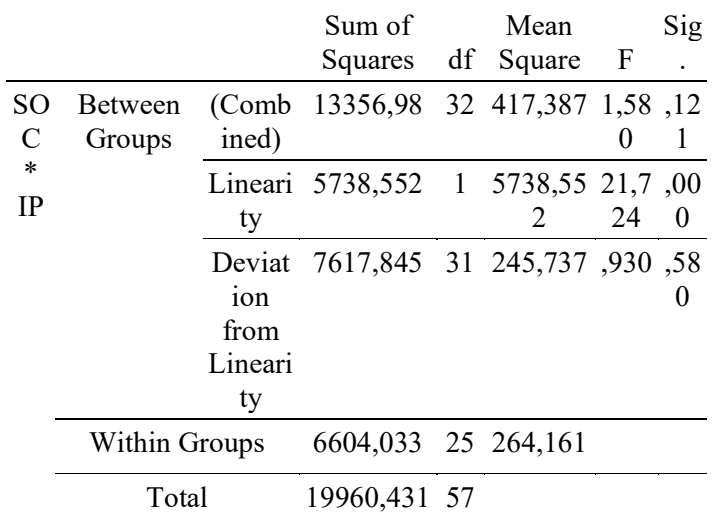

Dengan menggunakan uji korelasi Pearson diperoleh koefisien korelasi antara illness perception dengan sense of coherence sebesar 0,536 dengan nilai signifikansi sebesar 0,000 $(\mathrm{p}<0,05)$ yang berarti ada hubungan yang positif dan signifikan antara illness perception dan sense of coherence. Makin tinggi illness perception maka semakin tinggi pula sense of coherence yang dimiliki oleh pasien DM tipe 2.

Peneliti juga melakukan uji korelasi Pearson antara illness perception dan sense of coherence pada tiap kategori data demografi.

Tabel 6. Korelasi Illness Perception dan SOC berdasarkan data demografi

\begin{tabular}{ccc}
\hline Data Demografi & $\mathrm{r}_{\mathrm{xy}}$ & Signifikansi \\
\hline Pria & 0,583 & 0,003 \\
\hline Wanita & 0,533 & 0,000 \\
\hline Dewasa Madya & 0,527 & 0,003 \\
\hline Dewasa Akhir & 0,549 & 0,001 \\
\hline $\mathrm{DM}<5$ tahun & 0,413 & 0,008 \\
\hline $\mathrm{DM} \geq 5$ tahun & 0,650 & 0,000 \\
\hline
\end{tabular}




\section{PEMBAHASAN}

Pada penelitian ini terdapat hipotesis ada hubungan positif dan signifikan antara illness perception dan sense of coherence pada pasien DM tipe 2 di Puskesmas Kedungmundu. Hasil penelitian yang menunjukkan koefisien korelasi $\left(\mathrm{r}_{\mathrm{xy}}\right)=0,536$ dengan nilai signifikansi 0,000 $(\mathrm{p}<0,05)$ yang berarti ada hubungan positif yang signifikan antara illness perception dan SOC pada pasien DM tipe 2 di Puskesmas Kedungmundu. Dengan demikian hipotesis penelitian dapat diterima. Hal ini berarti semakin tinggi illness perception maka semakin tinggi juga SOC yang dimiliki oleh pasien DM tipe 2, begitu pula sebaliknya, semakin rendah illness perception maka semakin rendah juga SOC pada pasien DM tipe 2. Hasil ini sejalan dengan penelitian Lo Sterzo dan Orgeta (2015) yang menunjukkan bahwa persepsi terhadap penyakit memengaruhi SOC.

Penelitian yang dilakukan Lin, Gleason, dan Heidrich (2012) menunjukkan bahwa persepsi penyakit tidak hanya membantu individu memahami penyakit yang dideritanya namun juga bagaimana atribusi penyakit dapat memengaruhi penyesuaian dan penanganan psikologis. Dengan mengetahui atribusi penyakit individu mampu melakukan kontrol yang tepat terhadap kejadian dalam kehidupannya sehingga memiliki sedikit tekanan emosional. Hal ini berarti secara tidak langsung persepsi penyakit memengaruhi individu untuk memiliki keyakinan bahwa kejadian tersebut rasional (comprehensibility), bisa di atasi (manageability) dan memiliki makna bagi individu untuk layak diperjuangkan (meaningfulness). Comprehensibility, manageability dan meaningfulness merupakan dimensi dari SOC (Surtees, Wainwright, Luben, Khaw \& Day, 2003).

Penelitian yang dilakukan Lo Sterzo dan Orgeta (2015) menjelaskan bahwa aspek kognitif dan aspek afektif dari persepsi penyakit terkait dengan kemampuan untuk membingkai ulang stressor sebagai tantangan, menemukan makna dan perasaan percaya diri mengelola situasi. Individu yang memiliki persepsi negatif terhadap penyakit, cenderung menganggap hidup kurang bermakna, memiliki sumber daya yang lebih sedikit untuk mengatasi peristiwa sulit dan kurang mampu mengelola situasi. Di sisi lain, individu dengan persepsi penyakit yang baik memiliki SOC lebih tinggi dan dapat berkontribusi pada manajemen penyakit yang lebih baik khususnya pada pasien DM tipe 2 .

Sumbangan efektif illness perception terhadap sense of coherence sebesar 28,7\%. Hal ini berarti sebagian besar illness perception memberikan pengaruh terhadap SOC pada pasien DM tipe 2, sisanya sebesar $71,3 \%$ dipengaruhi oleh faktor-faktor lain. Hasil penelitian dari Odajima dan Sumi (2017) mengatakan bahwa faktor-faktor lain yang memengaruhi SOC pada penderita DM tipe 2, yaitu: usia, status sosial dan ekonomi (termasuk pekerjaan dan status pekerjaan), farmakoterapi bagi pasien diabetes, perubahan pola hidup (pola makan dan olahraga).

Pada penelitian juga ditemukan bahwa koefisien korelasi antara illness perception dan SOC pada pasien yang mengidap penyakit dalam kurun waktu $<5$ tahun lebih kecil dibandingkan koefisien korelasi illness perception dan SOC pada pasien yang mengidap penyakit dalam kurun waktu $\geq 5$ tahun. Hal ini menunjukkan bahwa pasien DM tipe 2 yang mengidap DM lebih dari 5 tahun sudah dapat beradaptasi dengan situasi atau tuntutan yang harus dijalani, seperti minum obat secara rutin, melakukan kontrol gula darah setiap bulan, melakukan diet, ataupun tuntutan lainnya yang merupakan adaptasi koping menuju akhir yang sehat dari suatu penyakit. Adaptasi koping menunjukkan bagaimana seseorang menghadapi stressor yang merupakan bagian dari konsep SOC (Antonovsky, 1987).

Hasil penelitian menunjukkan fakta bahwa illness perception yang dimiliki oleh pasien DM tipe 2 di Puskesmas Kedungmundu kebanyakan berada pada kategori sedang. Hal ini menunjukkan bahwa rata-rata pasien memiliki persepsi yang baik 
terhadap penyakit DM tipe 2 yang diderita. Sedangkan, untuk SOC yang dimiliki oleh pasien DM tipe 2 berada pada kategori sedang, sehingga dapat dikatakan bahwa pasien memiliki SOC yang baik.

Dalam penelitian ini ditemukan bahwa 66\% partisipan mayoritas berjenis kelamin perempuan. Prevalensi kejadian DM tipe 2 pada wanita lebih tinggi daripada pria. Wanita lebih berisiko mengidap diabetes karena secara fisik wanita memiliki peluang peningkatan indeks masa tubuh yang lebih besar dikarenakan sindroma siklus bulanan (premenstrual syndrome), pasca-menopause membuat distribusi lemak tubuh menjadi mudah terakumulasi (Irawan, 2010). Dalam penelitian juga ditemukan usia partisipan berada di rentang masa dewasa madya dan masa dewasa akhir. Hal ini dikarenakan peningkatan risiko diabetes seiring dengan umur, khususnya pada usia lebih dari 40 tahun, disebabkan karena pada usia tersebut mulai terjadi peningkatan intoleransi glukosa (Sujaya, 2009).

Penelitian ini telah dilaksanakan sesuai dengan prosedur ilmiah, namun tentunya masih memiliki keterbatasan, yaitu:

1) Setting pengambilan data saat kegiatan Prolanis ketika partisipan sedang menunggu antrian pemeriksaan, dan cukup ramai sehingga partisipan merasa terganggu oleh orang lain.

Peneliti tidak menetapkan batas usia maksimal partisipan yang akan berpartisipasi dalam penelitian sehingga banyak partisipan berusia pada masa dewasa akhir. Dikarenakan hal tersebut banyak partisipan yang sulit untuk membaca dan mengisi kuesioner sehingga harus didampingi oleh peneliti.

\section{KESIMPULAN}

Dari penelitian ini, dapat disimpulkan bahwa ada hubungan yang positif signifikan antara Illness Perception dengan Sense of Coherence (SOC) pada pasien Diabetes Melitus tipe 2 di Puskesmas Kedungmundu. Setelah penelitian ini dilakukan, ada beberapa saran yang dianjurkan oleh peneliti.
1) Pasien DM tipe 2 disarankan untuk dapat mempertahankan persepsi positif terhadap penyakit yang telah dimiliki dengan cara mengikuti sosialisasi di Puskesmas Kedungmundu untuk menambah informasi yang benar tentang penyakit DM tipe 2 terutama mengenai cara mencegah naiknya kadar gula darah.

2) Bagi penelitian selanjutnya, agar lebih memperhatikan setting tempat yang akan digunakan dalam pengambilan data. Diharapkan juga peneliti selanjutnya bisa menentukan batas maksimal usia partisipan. Penelitian selanjutnya juga dapat meneliti variabel lain yang erat kaitannya dengan SOC seperti usia, status sosial dan ekonomi, farmakoterapi bagi pasien DM tipe 2 dan perubahan pola hidup.

\section{DAFTAR PUSTAKA}

Abdelgadir, M., Shebeika, W., Eltom, M., Berne, C., \& Wikblad, K. (2009). Health related quality of life and sense of coherence in Sudanese diabetic subjects with lower limb amputation. The Tohoku Journal of Experimental Medicine, 217(1), 45-50.

Antonovsky, A. (1987). Unraveling the mystery of health: How people manage stress and stay well. Jossey-bass.

Antonovsky, A. (1993). The structure and properties of the sense of coherence scale. Social Science \& Medicine, 36(6), 725-733.

Arikunto, S. (2002). Prosedur penelitian suatu pendekatan dan praktek. Jakarta: Rineka Cipta.

Azwar, S. (2012). Reliabilitas dan validitas. $\left(4^{\text {th }}\right.$ ed). Yogyakarta: Pustaka Pelajar.

Bernell, S., \& Howard, S. W. (2016). Use your words carefully: what is a chronic disease?. Frontiers in public health, 4, 159.

Broadbent, E., Petrie, K.J., Main, J., \& Weinman, J. (2006). The brief illness perception questionnaire (BIPQ). Journal of Psychosomatic Research, 60, 631-637. Cohen, M., \& Kanter, Y. (2004). Relation 
between sense of coherence and glycemic control in type 1 and type 2 diabetes. Behavioral Medicine, 29(4), 175-185.

Delgado, C. (2007). Sense of coherence, spirituality, stress and quality of life in chronic illness. Journal of Nursing Scholarship, 39(3), 229-234.

Delgado, C. (2007). Sense of coherence, spirituality, stress and quality of life in chronic illness. Journal of Nursing Scholarship, 39(3), 229-234.

Funnell, M. M., \& Anderson, R. M. (2004). Empowerment and self-management of diabetes. Clinical Diabetes, 22(3), 123127.

Gallagher, R., Donoghue, J., Chenoweth, L., \& Stein-Parbury, J. (2008). Selfmanagement in older patients with chronic illness. International Journal of Nursing Practice, 14(5), 373-382.

Graham, C., Ballard, C., \& Sham, P. (1997). Carers' knowledge of dementia, their coping strategies and morbidity. International Journal of Geriatric Psychiatry, 12(9), 931-936.

Hakanen, J. J., Feldt, T., \& Leskinen, E. (2007). Change and stability of sense of coherence in adulthood: Longitudinal evidence from the healthy child study. Journal of Research in Personality, 41(3), 602-617.

IDF. (2017). IDF diabetes atlas: Eight edition. Retrieved from https://www.idf.org/ouractivities/advocacy-awareness/resourcesand-tools/134:idf-diabetes-atlas-8thedition.html.

Irawan, Dedi. 2010. Prevalensi dan faktor risiko kejadian diabetes melitus tipe 2 di Daerah Urban Indonesia: Analisa Data Sekunder Riskesdas 2007 (Thesis tidak dipublikasikan). Universitas Indonesia.

Karlsson, I., Berglin, E., \& Larsson, P. A. (2000). Sense of coherence: Quality of life before and after coronary artery bypass surgery - a longitudinal study. Journal of Advanced Nursing, 31(6), 1383-1392.
Kuuppelomäki, M., \& Utriainen, P. (2003). A 3 year follow-up study of health care students' sense of coherence and related smoking, drinking and physical exercise factors. International Journal of Nursing Studies, 40(4), 383-388.

Langius A. \& Bjo“"rvell H. (1996) Salutogenic model and the use of the sense of coherence in nursing research - a methodological report. Nursing Science and Research in The Nordic Countries, 16(1), 28-32

Leksell, J. K., Wikblad, K. F., \& Sandberg, G. E. (2005). Sense of coherence and power among people with blindness caused by diabetes. Diabetes Research and Clinical Practice, 67(2), 124-129.

Li, S. M., \& Shiu, A. T. Y. (2008). Sense of coherence and diabetes psychosocial selfefficacy of members of a peer-led organization in Hong Kong. Journal of Clinical Nursing, 17, 1526-1528.

Lin, F., Gleason, C. E., \& Heidrich, S. M. (2012). Illness representations in older adults with mild cognitive impairment. Research in Gerontological Nursing, 5(3), 195-206.

Lindmark, U., Stegmayr, B., Nilsson, B., Lindahl, B., \& Johansson, I. (2005). Food selection associated with sense of coherence in adults. Nutrition Journal, 4(1), 9.

Lo Sterzo, E., \& Orgeta, V. (2015). Illness representation and sense of coherence in dementia caregiving. Journal of Health Psychology, 22(6), 722-732.

Lundman, B., \& Norberg, A. (1993). The significance of a sense of coherence for subjective health in persons with insulindependent diabetes. Journal of Advanced Nursing, 18(3), 381-386.

Moss-Morris, R., Weinman, J., Petrie, K., Horne, R., Cameron, L., \& Buick, D. (2002). The revised illness perception questionnaire (IPQ-R). Psychology and Health, 17(1), 1-16.

Neuner, B., Miller, P., Maulhardt, A., WeissGerlach, E., Neumann, T., Lau, A., Brähler, E., Helmert, U., Haas, N., 
Müller, J.M., Spies, C., \& Wernecke, K. D. (2006). Hazardous alcohol consumption and sense of coherence in emergency department patients with minor trauma. Drug and Alcohol Dependence, 82(2), 143-150.

Odajima, Y., \& Sumi, N. (2017). Factors related to sense of coherence in adult patients with type 2 diabetes. Nagoya Journal of Medical Science, 80(1), 61.

Pallant, J. F., \& Lae, L. (2002). Sense of coherence, well-being, coping and personality factors: further evaluation of the sense of coherence scale. Personality and individual differences, 33(1), 39-48.

Proctor, R., Martin, C., \& Hewison, J. (2002). When a little knowledge is a dangerous thing...: a study of carers' knowledge about dementia, preferred coping style and psychological distress. International Journal of Geriatric Psychiatry, 17(12), 1133-1139.

Rahmawati, F., Setiawati, E. P., \& Solehati, T. (2014). Pengaruh dukungan keluarga terhadap kualitas hidup pasien diabetes mellitus tipe 2. Bandung: Universitas Padjadjaran.

Robiyanto., Prayuda, O. A., \& Nansy, E. (2016). Uji validitas instrumen B-IPQ versi Indonesia pada pasien hipertensi di RSUD Sultan Syarif Mohamad Alkadrie Pontianak. Social Clinical Pharmacy Indonesia Journal, 1(1), 41-49.

Sandén-Eriksson, B. (2000). Coping with type-2 diabetes: the role of sense of coherence compared with active management. Journal of Advanced Nursing, 31(6), 1393-1397.

Semarang, D. K. K. (2015). Profil kesehatan kota Semarang tahun 2015. Semarang: ET AL Semarang.
Semarang, D. K. K. (2017). Profil kesehatan kota Semarang tahun 2017. Semarang: ET AL Semarang.

Sugiyono, D. R. (2006). Statistika untuk penelitian. Bandung: CV. Alfabeta

Sujaya, I Nyoman. (2009). Pola konsumsi makanan tradisional Bali sebagai faktor risiko diabetes melitus tipe 2 di Tabanan. Jurnal Skala Husada, 6(1), 75-81.

Surtees, P., Wainwright, N., Luben, R., Khaw, K. T., \& Day, N. (2003). Sense of coherence and mortality in men and women in the EPIC-Norfolk United Kingdom prospective cohort study. American Journal of Epidemiology, 158(12), 1202-1209.

Sutton, S., Baum, A., \& Johnston, M. (2004). The SAGE handbook of health psychology. London: Sage Publication.

Taylor, S. E. (2009). Health psychology seventh edition. USA: McGraw-Hill.

Volanen, S. M., Suominen, S., Lahelma, E., Koskenvuo, M., \& Silventoinen, K. (2007). Negative life events and stability of sense of coherence: A five-year follow-up study of Finnish women and men. Scandinavian Journal of Psychology, 48(5), 433-441.

Weinman, J., Petrie, K. J., Moss-Morris, R., \& Horne, R. (1996). The illness perception questionnaire: A new method for assessing the cognitive representation of illness. Psychology and Health, 11(3), 431-445.

WHO. (2016). Global report on diabetes. Retrieved from https://apps.who.int/iris/bitstream/handle /10665/204871/9789241565257_eng.pdf ;jsessionid=730CB5639BD88849C3EA5 1C36EC25A81?sequence $=1$. 